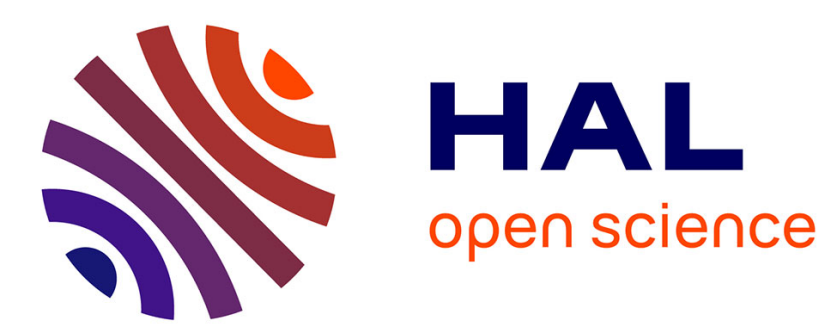

\title{
The Welfare Consequences of Centralization: Evidence from a Quasi-Natural Experiment in Switzerland
}

\author{
Sarah Flèche
}

\section{To cite this version:}

Sarah Flèche. The Welfare Consequences of Centralization: Evidence from a Quasi-Natural Experiment in Switzerland. Review of Economics and Statistics, 2021, 103 (4), pp.621-635. 10.1162/rest_a_00894. hal-02613181

\section{HAL Id: hal-02613181 https://hal-amu.archives-ouvertes.fr/hal-02613181}

Submitted on 26 May 2020

HAL is a multi-disciplinary open access archive for the deposit and dissemination of scientific research documents, whether they are published or not. The documents may come from teaching and research institutions in France or abroad, or from public or private research centers.
L'archive ouverte pluridisciplinaire HAL, est destinée au dépôt et à la diffusion de documents scientifiques de niveau recherche, publiés ou non, émanant des établissements d'enseignement et de recherche français ou étrangers, des laboratoires publics ou privés. 


\section{THE WELFARE CONSEQUENCES OF \\ CENTRALIZATION: EVIDENCE FROM A QUASI- \\ NATURAL EXPERIMENT IN SWITZERLAND ${ }^{1}$}

\section{Sarah Flèche ${ }^{2}$}

Abstract: Many countries are reallocating tasks and powers to more central levels of government. To identify centralization's welfare effects, I use a difference-in-differences design that relies on time and cross-cantonal variation in the implementation of centralization reforms in Switzerland. I find that centralization provokes significant decreases in residents' life satisfaction. I identify one mechanism driving the effect, namely the procedural disutility that individuals experience from having less influence over the formulation of political decisions. This effect is largest among individuals with higher expected benefits from being involved in the political decision process, with detrimental effects on local political participation.

JEL codes: D61, D72, H75, I31

\footnotetext{
${ }^{1}$ Acknowledgements: I am grateful to Clément Bosquet, Andrew Clark, Sergei Guriev, Steve Pischke, Nattavudh Powdthavee, Eugenio Proto, Claudia Senik, and Aloïs Stutzer for helpful comments and discussions. I also thank seminar and conference participants at the LSE, PSE, ESE and the IAAE, AFSE, LAGV, RES, SAEE meetings. This work was supported by the U.S. National Institute on Aging, the John Templeton Foundation, the What Works Centre for Wellbeing and the French National Research Agency Grant (ANR-17-EURE-0020).

${ }^{2}$ Affiliation: Aix Marseille University, CNRS, EHESS, Centrale Marseille, Aix-Marseille School of Economics, Marseille, France and CEP, London School of Economics. E-mail: sarah.fleche@univ-amu.fr
} 


\section{Introduction}

After decades of widespread reallocation of tasks and powers to subnational governments, many countries have begun to question the results of their decentralization efforts and have even started to reverse them (Treisman, 2007; Maleski et al., 2014). This trend toward "recentralization" has been strengthened by the recent economic and financial crisis, which has led several countries to reorganize their institutional systems to reduce public expenditure and public debt, and avoid the overlapping of responsibilities (IEB, 2013). These new institutional settings might have important consequences on residents' welfare, particularly as many countries are facing significant loss of trust in their institutions (OECD, 2013).

The literature has offered a wealth of hypotheses connecting (de)centralization to a variety of local outcomes. However, the causal impact of (de)centralization on individuals' welfare remains badly understood. Conventional decentralization studies suggest that granting authority to more centralized levels of governments should decrease individuals' control over political decisions and result in political outcomes being further away from individuals' preferences (Tiebout, 1956; Oates, 1972; Lockwood 2002; Besley \& Coate, 2003). However, more recent work has begun to question these theories. In particular, empirical evidence shows that decentralization may be less efficient, as decisions and implementation are postponed by different levels of government (Treisman, 2007) and the provision of public goods is divided too narrowly to allow economies of scale (Bardhan \& Mookherjee, 2008). Moreover, local governments are more vulnerable to capture by local elites than central governments (Bardhan \& Mookherjee, 2006).

Although the impact of (de)centralization on public-goods provision is crucial for residents' welfare, other mechanisms could be at work. If centralization reduces opportunities to influence political decisions and involvement in the political process, then it could decrease the utility that individuals derive from the political process itself (Frey \& Stutzer, 2000). Frey 
and Stutzer have interpreted this additional welfare effect as revealing the existence of an alternative concept of utility, namely procedural utility (Frey et al., 2004). This could ultimately lower the welfare benefits from centralization and decrease political participation, including voter turnout. This may also affect individuals' feeling of community belonging and affective attachment to their locality, as ties with their local representatives become weaker. These concerns are especially pertinent in countries where local political engagement has already reached unprecedented low levels (Bartels, 2016; Gilens, 2014; Solt, 2008).

Few empirical studies have examined the direct link between (de)centralization and individuals, particularly in terms of well-being. Using subjective well-being data, existing work has provided evidence that decentralization is associated with higher levels of life satisfaction (Frey \& Stutzer, 2000; Bjornskov et al., 2008; Voigt \& Blume, 2012; DiazSerrano \& Rodriguez-Pose, 2012; Gao et al., 2014; Sujarwoto \& Tampubolon, 2015). Frey and Stutzer (2000) implement a cross-cantonal econometric analysis using data on 6,000 residents in Switzerland and provide evidence that in cantons where the degree of local autonomy is higher, individuals report higher levels of life satisfaction. Bjornskov et al. (2008), Voigt and Blume (2012), and Diaz-Serrano and Rodriguez-Pose (2012) replicate the same analysis using cross-country data. However, these studies rely on cross-sectional variations and thus cannot disentangle the effects of decentralization from other omitted variables, including the socio-cultural and political contexts. In contrast, natural experiments can help us to evaluate the effect of (de)centralization reforms.

In this paper, I provide the first causal estimates of the impact of centralization reforms on individual well-being. I exploit time and cross-cantonal variations in the implementation of local centralization reforms that were introduced between 2000 and 2014 in Switzerland, and combine this information with panel data from the Swiss Household Panel (SHP) on 
individuals' life satisfaction. ${ }^{3}$ This allows us to use a difference-in-difference strategy, in which I compare changes in life satisfaction for people living in Swiss cantons that implemented a centralization reform in a given year with a comparison group of people with similar characteristics who lived in other Swiss cantons but did not experience a centralization reform in that year. Switzerland provides an ideal experiment for this analysis, as the local centralization reforms were the result of national incentives to reallocate tasks and powers between cantons and municipalities. The centralization has transferred responsibilities in a broad range of domains such as health, education, social affairs, and public administration (reflected by a decline of roughly six percentage points in the share of municipal expenditure in the total amount of cantonal expenditure). The timing of implementation was quasirandom, and these transfers have been well publicized among Swiss citizens.

My difference-in-difference estimates show that centralization ${ }^{4}$ provokes a small decrease in life satisfaction. Quantitatively, centralization reforms reduce life satisfaction by 0.063 on a 0-10 scale, equivalent to $4.36 \%$ of a standard deviation (SD). The effect is small but economically and statistically significant, equivalent to the effect of a $0.633 \mathrm{SD}$ increase in neighborhood poverty (Ludwig et al., 2012).

A range of checks validates my identifying assumption and demonstrates robustness to alternative specifications. Supporting the parallel-trends assumption, placebo tests indicate no differential pre-trends in life satisfaction across treated cantons. My results also hinge on the assumption of quasi-random variations in the relative timings of centralization reforms, conditional on canton fixed effects and a large set of observable characteristics. I demonstrate

\footnotetext{
${ }^{3}$ Cantons are a type of administrative division. Cantons roughly correspond to "regions" or "semi-sovereign states" when compared with other administrative divisions. They are larger than municipalities in terms of area and population. There are 26 cantons in Switzerland.

${ }^{4}$ Captured by a dummy variable equal to 1 if any centralization reform took place in a canton.
} 
that there is no statistically significant relationship between centralization reforms and the socioeconomic characteristics of a canton. Furthermore, I present several checks suggesting that my results are unlikely to be explained by selective migration. I provide evidence that the effects of the reforms are not policy specific (such as health, education, and social affairs related). Finally, I obtain similar results by using measures of reform intensity and interacting them with my reform indicator.

Investigating potential mechanisms, I find that the procedural impact of centralization plays a key role. The reforms decreased the probability of people reporting having political influence by 1.15 percentage points. This loss of political influence reduces individuals' expected benefits of participating in the political decision process and significantly decreases local political engagement. I use cantonal and municipal administrative data from la Base de Données des Cantons et Villes Suisses (BADAC) and the National Survey of Local Secretaries (NSLS) to show that individuals were less likely to participate in municipal actions (including municipal popular initiatives, referenda, protests, and making contact with the executives or the administration) and were less involved in community associations after implementation of the reforms.

Addressing the possibility that centralization may also result in local government services being further away from individuals' preferences, I find evidence that centralization reforms restrained municipal and cantonal expenditure levels. However, individuals were not less satisfied with public expenses. If anything, the decline in public spending allowed municipalities and cantons to implement tax cuts and improve the transparency of local public finance, thereby ensuring increases in annual household income by roughly $1.18 \%$ over the period.

The decrease in life satisfaction has been concentrated among individuals who have higher expected benefits from being involved in the political decision process. To provide evidence 
for this, I compare centralization effects between eligible voters, who have the right to vote and participate in the political decision process, and non-voters: Eligible voters suffered from centralization, and non-voters to a lesser extent. While both groups are exposed to centralization outcomes - they both benefit from public-goods provision and are liable to pay taxes - the well-being differential between these two groups could be seen as additional evidence of decreasing political influence for eligible voters, as the existence of a procedural disutility effect would imply.

As a final exercise, I leverage my research design and investigate whether the welfare effects of centralization are sustained or even strengthened under certain political conditions. I first provide evidence that negative effects of centralization are higher for individuals living in cantons with a lower degree of direct democracy. A 1 SD decrease in the degree of direct democracy (reflected by a decline of roughly 1 point on a 1-6 scale) raises the negative effect of centralization by 0.051 , supporting the idea that providing more opportunities to participate could help mitigate the negative effects of centralization. Second, I compare cantons where the reforms have been approved with a low margin against cantons where there has been higher approval. This allows us to test whether the conditions under which the reforms have been implemented matter. In cantons where the reforms have been well approved, there is evidence of a small decrease in life satisfaction. In cantons where the reforms have been highly debated and less expected, the negative effect is much stronger. Even if outcome considerations are important, this suggests that a centralization decision may be judged differently by citizens, depending on whether they perceive the political decision leading to centralization as being fair or not.

This paper contributes to several strands of the literature. First, I exploit a quasi-natural experiment that allows us to explore empirically the causal impacts of centralization on individuals. In contrast to the existing literature (e.g., Davoodi \& Zou, 1998; Faguet, 2004; 
Iimi, 2005; Enikolopov \& Zhuravskaya, 2007; Barankay \& Lockwood, 2007; Rodrigez-Pose \& Ezcurra, 2011; Sepulveda \& Martinez-Vazquez, 2011), I go beyond efficiency considerations by providing unique insights into how people perceive centralization reforms. The results reveal that even if centralization may reduce public expenditure and avoid the overlapping of responsibilities, it also induces welfare costs. An inability to take these into account might fail to capture centralization's overall effects. These findings are highly relevant for the many developed and developing countries currently questioning their decentralization efforts and reallocating tasks and powers to more central levels. By providing evidence that centralization reduces the probability of people reporting having political influence, my paper also contributes to a nascent literature that has shown the impact of (de)centralization on voters' political participation (Michelsen et al., 2014; Revelli, 2016).

More generally, although other mechanisms are presumably at work, these results support theories that have established the existence of procedural utility: the underlying assumption that individuals derive utility from the procedures or institutions applied. Although it has often been noted, this assumption has barely been studied empirically. The few examples include consumers' reactions to different allocation mechanisms (Kahneman et al., 1997; Frey \& Pommerehne, 1993), employees confronted with different organizational procedures (Benz \& Frey, 2003; Benz \& Stutzer, 2003; Marmot, 2004), and voters' procedural benefits obtained from direct democracy institutions (Frey \& Stutzer, 2005; Stutzer \& Frey, 2006; Frey et al., 2008). ${ }^{5}$ I complement this literature by focusing on a particular procedure: the allocation of decision-making and taxing powers between different levels and across different jurisdictions.

\footnotetext{
${ }^{5}$ More generally, some economists have long been interested in the analysis of procedures applied (e.g., Simon, 1976, 1978; Sen, 1995; Tyler, 2006). This literature argues that economics must give an amount not only to the extent to which appropriate allocations are
} 
The paper proceeds as follows. Section II introduces the Swiss context and the centralization reforms. Section III presents the data and the empirical strategy. Section IV describes the central results of the paper and robustness checks. Section V tests for underlying mechanisms, sections VI and VII discuss heterogeneous effects, and section VIII concludes.

\section{The Swiss Context and the Reforms}

This section provides a brief overview of the Swiss system, before detailing the centralization reforms underpinning my identification strategy.

\section{A. The Swiss System}

There are three administrative levels in Switzerland: the Federation, cantons, and municipalities. The Federation is divided into 26 sovereign cantons, each of which has its own constitution and unicameral parliament. The cantons exercise broad authority, possessing all the powers that are not specifically given to the federal government. The third administrative level is the municipality, ${ }^{6}$ which has autonomy within the limits of the federal and cantonal jurisdictions. The Federation grants autonomy to each municipality and introduced a new article in the last Federal Constitution of 18 April 1999 (SR/CH 101, art. 50, para. 1), which stipulates: "The autonomy of the municipalities is guaranteed in accordance with cantonal law." The municipality governments and their deciding and acting autonomy are well recognized within this constitutional article, which moreover justifies the right to maintain municipal responsibilities.

This autonomy of the municipalities is feasible for three reasons. First, municipal governments can access sufficient resources and use them autonomously. In 2008, the share

chosen, but also to the procedures used to choose allocations. However, little research has empirically investigated this question.

${ }^{6}$ There are approximately 2,500 municipalities in Switzerland. 
of total resources was close to $30 \%$ for the Federation, $40 \%$ for the cantons, and $30 \%$ for the municipalities, based on local taxes and revenues. Municipalities thus control almost the same amount of income as the Federation (Swiss Federal Statistics, 2008). Second, accountability and transparency at the cantonal and municipal levels are guaranteed by direct democratic instruments in addition to representative democratic parliaments and governments. The most important direct democratic instruments in cantons are the popular initiative to change the canton's constitutions or laws, compulsory referenda to prevent new laws and the changing of existing laws, and optional referenda to prevent new state expenditure. Therefore, all citizens participate and play an active role in political life at the cantonal and municipal level. Third, there exists a strong legal framework clearly setting out the powers, rights, and duties of cantonal and municipal governments.

Traditionally, many responsibilities are shared between the Swiss cantons and the local municipalities, such as education, local police, policy relating to culture, sports, youth and the elderly, building and surveillance of local roads, the local public transport system, health (home care, fighting addiction, health promotion), public welfare, and the environment (waste management and water treatment). However, because of the right of the cantons to organize themselves independently, there is considerable variation in cantonal and municipal government structures with regard to the division of competences between cantons and municipalities ("the extent of municipal autonomy").

\section{B. The Centralization Reforms}

Between 2000 and 2014, 19 out of the 26 Swiss cantons launched reforms to change the distribution of tasks and responsibilities between cantons and municipalities. According to experts in public administration, a first analysis of the reforms clearly shows a centralization 
movement (Jacot-Descombes, 2013; Ruhli, 2012). ${ }^{7}$ The impact of the reforms on the degree of local decentralization (measured by the share of municipal expenditure in the total amount of cantonal expenditure) can be seen in figure 1, which shows the deviation from mean degree of local decentralization before and after the reforms. The average degree of local decentralization after implementation of the reforms decreased by six percentage points, when comparing only one year before the reforms with one year after adoption.

\section{[Figure 1 about here]}

There are a number of reasons behind these reforms. First, the purpose of the reforms was to increase cantonal responsibilities and restrain public spending. Cantons face large variations across municipalities in terms of financial and administrative capacity. Specifically, municipalities in large cantons such as Vaud, Lucerne, Aargau, and Bern have difficulties in dealing with tasks delegated to them and need financial support. These reforms therefore aimed to help municipalities to deal with economic pressures and to improve the transparency of local public finance (Jacot-Descombes, 2013). Second, these reforms followed the introduction of "New Public Management Reforms," which aimed to improve the efficiency of public action, and the introduction in 2008 of the "New Fiscal Equalization Reform," which changed the distribution of tasks and responsibilities between the Federation and cantons. Consequently, cantons had large incentives to reform their own legislation to anticipate and adapt to these national reforms.

Each canton has reformed at least one significant area-in financial terms-regarding schools (usually in primary/elementary and secondary schools), health (particularly hospitals),

\footnotetext{
${ }^{7}$ Jacot-Descombes (2013) reports results from the 2009 NSLS survey. Some $73 \%$ of local secretaries confirmed that there has been a new allocation of tasks between municipalities and cantons during the last ten years. The same proportion agrees that municipal autonomy has decreased.
} 
and social affairs (usually either social assistance and/or social insurance). Appendix tables A1 and A2 provide a detailed description of the centralization reforms. Transfers have occurred at the decision, financial, and implementation levels. In terms of implementation, social insurance is still shared between cantons and municipalities because municipalities act as good local relays to deliver benefits.

Education is clearly the area where most of the tasks have been transferred. This was a policy domain that remained highly decentralized. These reforms have unified school organization between cantons. For example, in the cantons of Bern and Vaud, responsibilities of secondary schools have been entirely transferred to the canton level. In Vaud, this is also the case for primary schools. The areas that have also been the most often affected are health and social services. In health, a strategy of "cantonalization" clearly appears in hospital systems (cantons of Neuchâtel, Jura, and Bern). Aargau, Graubünden, and Schwyz are the only cantons where the hospital system is not entirely centralized. Vaud also centralized its ambulance and emergency systems. Finally, the field of social and social insurance has been relatively centralized by the reforms, in particular with respect to standards governing social assistance and public support services, as well as tasks related to federal legislation regulating social security, including unemployment (Aargau and Bern), health insurance (Aargau and Bern), and additional services (Aargau and Neuchâtel). These three policy areas (schools, health, and social services) are where the cantons and municipalities allocate more financial resources, giving significant weights to all these transfers.

Interestingly, and crucially for my identification strategy, the reforms were not adopted at the same time across cantons. Cantons had large incentives to modify their own legislation and implement the reforms but were given the liberty to decide the exact timing themselves. In particular, municipalities were heavily involved and consulted during implementation of the reforms. Thus, the final timing of the reforms across cantons was partly determined by a 
legislative process. Most of the reforms were implemented in nineteen cantons between 2000 and 2014. There may have been some reforms in the seven remaining cantons, but by 2014 , they were limited or not yet implemented. Figure 2 shows the geographical distribution of the timing of the reforms. The spread of the reforms was not concentrated in certain parts of Switzerland, and early-, middle-, and late-reforming cantons are present in all parts of the country.

\section{[Figure 2 about here]}

For the identification strategy, the timing of the reforms does not need to be independent of fixed cantonal characteristics, given that canton fixed effects are controlled for in the estimations. However, it is informative to investigate what cantonal characteristics, if any, would predict the timing of the reforms across cantons. I estimate ordinary least-squares canton-level regressions, where the dependent variable is the year of the reform in each canton and the explanatory variables are pre-reform cantonal characteristics such as income per capita, population size, total public spending, income tax rates, financial and fiscal health, degree of decentralization, and degree of direct democracy. The analysis uses cantonal data from BADAC. ${ }^{8}$ Appendix table A3 provides further details on the canton-level variables used from this source, and appendix table A4 gives some descriptive statistics. I find no statistically significant relationship between the timing of the reforms and the cantonal characteristics considered. None of the explanatory variables are statistically significant. (See appendix table A5 for the detailed results.)

Swiss residents were - in most cantons - asked to vote for these centralization reforms. In addition, before voting, they were heavily involved and consulted. Therefore, the reforms were made visible and salient to all Swiss residents, reducing concerns about people's ignorance of changes in political structures (Shaker, 2012; Teske et al., 1993). The people

\footnotetext{
${ }^{8}$ www.badac.ch/fr/index.php.
} 
were able to find official information on the reforms in administrative reports, on their cantons' websites, or at local meetings organized by municipalities and/or cantons. Appendix table A6 presents search results in Swiss news media for four groups of key words, "EtaCom," which is the name of the reform implemented in Vaud, "municipal autonomy," "allocation of tasks between cantons and municipalities," and "revenue sharing (finanzausgleich)," using the Factiva database. ${ }^{9}$ Between 2000 and 2014, 190 newspaper articles were written on EtaCom, 4,245 articles on "municipal autonomy," 2,370 on "allocation of tasks between cantons and municipalities," and 21,065 on "revenue sharing." The content of these publications makes clear that the reforms were associated with more policymaking and implementation responsibilities being transferred to the cantons (some extracts are given in the online appendix). It also provides suggestive evidence that Swiss residents were well informed about the reforms and understood the nature of the policy change. ${ }^{10}$

\section{Data and Empirical Strategy}

\section{A. Data}

To evaluate the effect of these centralization reforms on Swiss individual well-being, the empirical analysis appeals to the SHP, which is a yearly panel study following a random

\footnotetext{
${ }^{9}$ Factiva aggregates content from both licensed and free sources, and provides access to newspapers, journals, and magazines from many countries, including Switzerland. http://factiva.com/sources/factivasearch/index_cs.aspx

${ }^{10}$ Figures $\mathrm{A} 1, \mathrm{~A} 2$, and $\mathrm{A} 3$ in the online appendix also present an analysis of Google queries such as "municipal autonomy," "allocation of tasks," and "revenue sharing," providing suggestive evidence of the salience of the reforms to Swiss residents.
} 
sample of households in Switzerland over time and interviewing all household members. ${ }^{11}$ The sample contains about 15,400 respondents, 14-99 years of age, observed on average seven times and for a total of approximately 130,000 observations. The period covered by the data is 1999-2014.

There are several advantages in using the SHP. First, it constitutes a unique database for Switzerland because it covers the 26 Swiss cantons. The samples are stratified by major region (Lake Geneva region, Mittelland, north-west Switzerland, Zurich, eastern Switzerland, central Switzerland, and Ticino), without any regional oversampling. Second, these are panel data collected on a consistent basis over cantons, municipalities, individuals, and years. Therefore, this allows us to analyze within-person changes in well-being over time and to control for a broad range of individual characteristics, including gender, age, marital status, employment, health, income, electoral status, citizenship, and political preferences - known to be predictors of individual well-being. The data also identify municipalities of residence.

Subjective well-being. In the SHP, subjective well-being is assessed through the question "In general, how satisfied are you with your life?" where respondents have eleven choices $(0=$ not at all satisfied, $10=$ very satisfied $)$. Life satisfaction is asked only over the period 2000-2014. Appendix table A8 shows means and SDs of the variables from the SHP and the distribution of life satisfaction. Of the sample, $15.2 \%$ report that they are very satisfied with their life [10]. Conversely, $1.8 \%$ answer that they are dissatisfied [0-4]. I also consider two alternative subjective variables: Satisfaction with public spending (0-1) and Feeling about political influence (0-1). Two important aspects of centralization are (i) whether political outcomes are closer or further away from individuals' preferences and (ii) the procedural utility that individuals derive from having political influence. To test for these two

\footnotetext{
11 More information can be found on the SHP at https://forscenter.ch/projects/swisshousehold-panel/
} 
mechanisms, I compute two variables: Satisfaction with public spending, which is a dummy equal to 1 for the $37.6 \%$ of the sample that report being satisfied with public expenses, and Feeling about political influence, which is a dummy equal to 1 for the $46 \%$ of the sample that report feeling or having political influence. The online appendix provides the exact wording and possible answers for these variables.

The validity of such subjective data may be a concern. Many issues remain unresolved regarding self-reported measures of well-being. However, there is substantial evidence that these measures are capable of accurate and meaningful information and provide indications of individuals' evaluation of their life satisfaction (see, among others, Frey \& Stutzer, 2002; Layard, 2005; Clark et al., 2018). A brief analysis also provides evidence that measures of subjective well-being from the SHP perform in the way the theory would suggest with respect to the construct being measured. For example, Life satisfaction and Satisfaction with public spending are shaped by socio-demographic factors such as age, income, employment, and marital status. Conversely, Feeling about political influence is associated with electoral status and citizenship. There is also evidence that respondents find these questions on subjective well-being easy to understand. They have very low non-response rates (less than $5 \%$ did not answer or selected "do not know").

Cantonal and municipal outcomes. I merge the SHP with administrative data to measure cantonal and municipal outcomes over the period under consideration. I use two sources: BADAC 2000-2014 and the NSLS 1998, 2005, 2009, and 2016.

BADAC is an administrative dataset that collects items from a variety of sources such as the Swiss Official Statistics, the Department of Finance, and the IDHEAP (the Swiss Graduate School of Public Administration) survey at the canton and municipality levels. It contains information on the Swiss cantons and their municipalities, their political administrative organization, and their public services in the years 2000-2014. This enables 
me to have detailed information on the quantity and quality of public-goods provision (total public expenditure, health, school, and social expenditure, and the degree of decentralization), municipal and cantonal fiscal capacity (revenue, income tax rates, equalization payments, cantonal financial health, and cantonal fiscal management), voter political participation (municipal, cantonal, and federal voter turnout), demographics (population size), and socioeconomic characteristics (unemployment rate). Summary statistics and detailed definitions of all these variables used from the BADAC dataset can be found in the online appendix.

I complement this information with the NSLS dataset collected by Andreas Ladner in 1998, 2005, 2009, and 2016 among local secretaries. ${ }^{12}$ This survey covers about $80 \%$ of the more than 2,500 Swiss municipalities, and provides additional measures of local public finance (municipal revenue and debt), as well as political participation (municipal, cantonal, and federal voter turnout), and less basic forms of political engagement (participation in municipal popular initiatives, referenda, and protests, and whether municipal residents make contact with the executives and the municipal administration). Appendix tables A9 and A10 provide a detailed description of these variables.

\section{B. Empirical Strategy}

To identify the effects of centralization on individuals' well-being, I take advantage of the cross-cantonal variation in the timing of implementation of the centralization reforms, which makes it possible to implement a difference-in-difference design. Specifically, I compare individuals' well-being in cantons that implemented a reform (treated group) with

12 Additional information can be found on Andreas Ladner's website: http://www.andreasladner.ch/forschung.html 
individuals' well-being in the remaining cantons (control group) before and after the policy change.

The well-being of individual $i$ living in canton $c$ in year $t$ can be defined as

$$
\mathrm{WB}_{\text {ict }}=\beta \mathrm{R}_{\mathrm{ct}}+\mathrm{X}_{\mathrm{ict}} \lambda+\mathrm{Z}_{\mathrm{ct}} \eta+\rho_{\mathrm{c}}+\mu_{\mathrm{t}}+\theta_{\mathrm{i}}+\varepsilon_{\mathrm{ict}}
$$

where $R_{c t}$ is a dummy equal to 1 where the centralization reform has been implemented in canton $c$ in year $t$, and $X_{i c t}$ is a vector containing individual controls such as equivalized household income, age, age squared, marital status, employment status, health status, educational level, first language, religion, citizenship, electoral status, and political preferences. The model includes individual fixed effects, $\theta_{i}$, which control for individual unobserved heterogeneity, including reporting style in answering the life satisfaction question. In addition, $\rho_{c}$ and $\mu_{t}$ refer to canton and year fixed effects, respectively. These fixed effects completely control for yearly influences and any fixed differences between cantons, for example, official language, degree of urbanization, culture, and political institutions. Therefore, the identification strategy in equation (1) relies on inter-temporal variations between cantons when adopting the reforms and within-person changes in self-reported wellbeing before and after the reform. To address spatial clustering of centralization reforms, standard errors are clustered by canton-year throughout. ${ }^{13}$

A crucial assumption to hold for the difference-in-difference strategy is that of a common trend: that individuals' well-being would have evolved similarly across cantons in the absence of the reforms. This assumption could be violated if cantons that have implemented the reforms faced specific shocks different to those in other cantons. In this case, equation (1) would possibly capture only different trends between the control and treated cantons. I plot the trend in mean life satisfaction across cantons according to exposure to the reforms (before

\footnotetext{
${ }^{13}$ Note that clustering at the canton level yields similar results.
} 
and after 2008) using the SHP. ${ }^{14}$ Figure 3 indicates that the lines track each other well from eight years prior and up to implementation of the reforms ${ }^{15}$ Nevertheless, I include timevarying cantonal controls, $Z_{c t}$, such as cantonal income per capita, cantonal unemployment rate, and cantonal population size. In most specifications, I also add canton-specific time trends in case other time-varying factors correlating with the implementation of the reforms would explain the results.

\section{[Figure 3 about here]}

We may also be concerned by other reforms occurring during the period under consideration (2000-2014). In particular, during the treatment period, financial equalization reforms were implemented between the federal and cantonal levels as well as within cantons. Some cantons profited from increased equalization payments while some lost payments. This might confound the treatment measure and again threaten the common-trend assumption. To limit this potential bias, I also include in equation (1) time-varying cantonal equalization payments. Note that I do not control for other cantonal characteristics such as public expenditure, income tax rates, or political participation, as these are likely to capture information on the mechanisms through which centralization reforms affect individuals' wellbeing; see section V.

${ }^{14}$ This roughly corresponds to dividing the treated cantons into two equal groups. Moreover, 2008 is the year of implementation of the "New Fiscal Equalization Reform" between the Federation and the cantons.

${ }^{15}$ Table 2 in section IV presents additional tests where I estimate a similar model as equation (1), but including indicators for centralization reforms set to 1, four, three, and two years prior to the reforms coming to effect. Individuals are not significantly affected by the centralization reforms in the years prior to implementation, consistent with the common-trend assumption. 


\section{Centralization and Life Satisfaction}

\section{A. Baseline Results}

Table 1 shows estimates of equation (1) using ordinary least-squares. The effect of the centralization reforms on life satisfaction is first estimated on the pooled cross-section (column 1) with canton and year fixed effects, but without cantonal time-varying controls. I progressively add an extensive list of individual controls (column 2) and cantonal controls (column 3). I then use the panel nature of the data to explore how centralization reforms affect within-person change in life satisfaction (column 4). Column 5 substitutes the cantonal fixed effects with municipal fixed effects for a robustness check.

The results show that the relationship between centralization reforms and life satisfaction is negative and statistically significant. With the full set of controls, the size of the estimate indicates that people exposed to centralization saw a decrease in life satisfaction of approximately 0.063 , equivalent to $4.36 \%$ of an SD. All the coefficients on individual and local controls have signs that are consistent with those in the literature (for detailed results, see appendix table A11).

\section{[Table 1 about here]}

The effect is larger than prior empirical findings examining the relationship between decentralization and individuals' subjective well-being. The cross-section estimates of Frey and Stutzer (2000) indicate that an increase in local autonomy is associated with an increase in life satisfaction of 0.033 (marginal effect), while Bjornskov et al. (2008) find a coefficient of 0.032 (using weighted ordered probit). However, my results could reflect short-term effects, while the cross-section estimates of Frey and Stutzer (2000) and Bjornskov et al. (2008) can be interpreted as long-term effects.

\section{B. Falsification Tests and Robustness Checks}


Table 2 revisits the results shown in table 1 by running several falsification tests and robustness checks. I first consider three placebo experiments by assuming that the centralization reforms were implemented four, three, and two years earlier. We might worry here that unobservable trends within cantons are driving the results. In rows (1), (2), and (3), I do not find any significant effect of these placebo reforms on life satisfaction. Additionally, appendix figure A4 asks whether the effect of the centralization reforms on individuals' life satisfaction varies at yearly intervals before and after the reforms come into effect. Consistent with the common-trend assumption, I find that individuals did not anticipate the well-being effects of the reform. In addition, individuals are negatively affected after implementation of the reforms, and the effects persist over time. This suggests that individuals adapt slowly to centralization negative effects.

Rows (4) and (5) then test whether my results could be driven by endogenous residential sorting, namely the possibility that individuals would move to cantons where political decisions are in accordance with their preferences. To address this concern, row (4) reestimates equation (1), but assigns each respondent to the canton in which they lived before implementation of the reforms (in 2000). ${ }^{16}$ Alternatively, in row (5), I include individualcanton fixed effects. In both cases, the coefficient on centralization reforms remains negative and statistically significant.

\section{[Table 2 about here]}

Next, row (6) of table 2 replicates the baseline results using probit adjusted ordinary leastsquares. Satisfaction responses are observed on an ordinal scale. A natural estimator in this case would be an ordered response model. This provides similar results. As centralization has

\footnotetext{
${ }^{16}$ To mitigate the concern that respondents migrating to other cantons drive the results, appendix table A12 also tests for the impact of centralization on the probability of moving to another canton. I find no evidence of selective migration.
} 
transferred responsibilities in a broad range of domains (such as health, school, and social affairs), we may also wonder whether the effects of centralization differ across these domains. To test for this, rows (7), (8), and (9) decompose the reform variable into three categories,

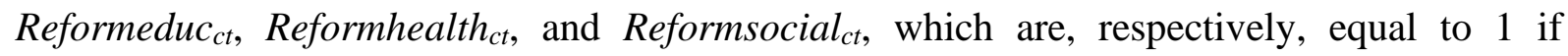
school, health, or social spending have been centralized by the reforms. Across all three specifications, the results are close to the baseline average estimates.

Finally, I provide evidence that the coefficient on the reform variable remains negative and statistically significant when interacted with the intensity of treatment in each canton. The centralization intensity is defined in row (10) by the number of tasks, which have been transferred from the municipalities to the cantons (see appendix table A2). In row (11), I define centralization intensity by the share of municipal expenditure that has been transferred to cantons (see figure 2). The results indicate that an increase by one percentage point in the centralization intensity would lead to a decrease in individuals' life satisfaction by 0.010 . This is in line with my previous results (see table 1).

\section{Potential Mechanisms}

These preceding results demonstrate that centralization significantly decreases individuals' life satisfaction. This section sheds light on the drivers of these negative effects by exploring two main channels: decreasing economic efficiency, leading to political outcomes being further away from individuals' preferences, and reducing procedural utility through perceived lower political influence.

\section{A. Economic Efficiency}

A first potential explanation for the decrease in life satisfaction is that centralization reforms go hand in hand with lower levels of public expenditure (e.g., health, school, and social affairs), resulting in reduced quality of public service delivery. To test for this idea, I repeat the difference-in-difference analysis by substituting measures of public expenditure to life 
satisfaction, where regressions are now estimated at the municipal and cantonal levels. The results, reported in table 3 , indicate that centralization reforms did reduce municipal and cantonal expenditure per capita. The effect is -37 Swiss francs for municipalities and -371 Swiss francs for cantons, respectively (columns 1 and 2). As the purpose of the reforms was to restrain public spending and help municipalities deal with economic pressures, observing negative effects on public expenditure levels may not be surprising. Nevertheless, this confirms that the effects of the centralization reforms agree with the predicted ones.

Lower levels of public expenditure can, in turn, imply lower levels of life satisfaction. However, this might not be the case if provision of local public goods was not optimal in the first place (Bjornskov et al., 2007). In column (3), I then test whether centralization significantly decreased individuals' satisfaction with public expenses. The results show no significant effect, providing evidence against the idea that centralization harmed the quality of local government services.

\section{[Table 3 about here]}

By contrast, I provide evidence that centralization reforms led to lower tax rates, with an effect of approximately -0.41 percentage points for municipalities and -0.29 percentage points for cantons (columns 4 and 5). In line with this, municipal revenues were more likely to be reduced (column 6), while no evidence is found that municipal debt increased over the period (column 7). Columns (8) and (9) also provide evidence that centralization did not significantly affect cantonal fiscal capacity, with no significant effect on cantonal financial health or cantonal fiscal management. As a result of these financial tax cuts, annual household income increased over the period, by precisely $1.18 \%$ (column 10 ).

\section{B. Political Influence and Participation}

A second potential explanation for the decrease in life satisfaction is that centralization may entail lower information levels and lower subjective feeling of being able to influence local 
politics. As political decisions are transferred to more central levels of government, centralization reforms would thus come with procedural costs, leading to lower satisfaction levels (Frey et al., 2004). In the SHP, respondents are asked whether they feel that they have political influence. I use this variable to test for this additional channel. Table 4, column (1) shows that centralization decreased the probability that respondents with full participation rights report having political influence by 1.15 percentage points.

If centralization reforms affected people's feeling about political influence, we might expect voter behaviors to have been altered. Columns (2-5) investigate the effect of centralization on voter turnout in the municipal, cantonal, and federal elections. The estimates suggest that voter turnout at municipal elections was not affected by the centralization reforms. In contrast, voter participation in cantonal elections significantly increased by 2.38 percentage points after implementation of the reforms. Similarly, columns (4) and (5) show that voter turnout at federal votations increased by 2.15 percentage points, and the number of times people voted at federal elections increased by 0.075 (on a 0-10 scale).

The evidence is consistent with the hypothesis that people use different decision criteria if they are called to exercise their right to vote in local versus more central elections. Arguably, centralization reforms decreased political influence, and the probability was reduced that one single voter would make a difference. Consistent with strategic voting behaviors (Downs, 1957), this decreased the expected utility from voting and made it more likely that people abstained. Although a decline in voting participation would be expected after centralization reforms, no such effect is observed. This argument is counterbalanced by a positive effect, as an increase in political responsibilities at the canton/federal level is likely to have raised the stakes of the cantonal and federal elections.

As additional evidence, I find that other forms of political and civic engagement have been affected. Columns (6-8) provide evidence that individuals were less likely to participate in 
municipal actions (including participation in municipal popular initiatives, referenda, protests, and making contact with the executives and the municipal administration) and less involved in community associations after implementation of the reforms. ${ }^{17} \mathrm{By}$ contrast, no evidence is found that centralization affected the probability of being a member of a political party.

\section{[Table 4 about here]}

Taken together, these results suggest that the procedural effects associated with centralization play a key role in shaping individuals' well-being impacts derived from centralization. If centralization decreases the feeling of having political influence, both involvement in and attachment with the local political system are likely to be affected. As a result, this decreases individuals' well-being.

\section{Heterogeneity by Electoral Status and Citizenship}

In a country where most residents participate and play an active role in political life at the cantonal and municipal levels, significant loss of political influence induced by centralization reforms is likely to have persistent effects on individuals' well-being. In this section, I examine whether life satisfaction decreases were concentrated among individuals with higher expected benefits from being involved in the political decision process.

More specifically, I take individuals' electoral status into consideration and perform a triple difference analysis. An individual's electoral status is defined using the question "Electoral status: Yes or No?” This includes respondents being aged 18 years or older and being Swiss citizens as well as foreigners in cantons where they have been granted the right to vote after they have lived a certain number of years in Switzerland. In the SHP, $85.3 \%$ of the respondents declare that they are eligible to vote (2000-2014). By contrast, non-eligible

\footnotetext{
${ }^{17}$ In the SHP, $14.5 \%$ of respondents report being a member of a local association. Similarly, $11 \%$ of respondents report being a member of a political party.
} 
voters, who do not have the right to vote, are less likely to derive utility from having influence over the political process. Any well-being differential between eligible voters and non-voters could therefore be interpreted as additional evidence of procedural disutility effects from centralization, assuming that these two groups would react in the same manner to the reforms - except for their belief in political influence.

I estimate the following equation:

$$
\mathrm{WB}_{\text {ict }}=\beta \mathrm{R}_{\mathrm{ct}}+\delta \mathrm{R}_{\mathrm{ct}} * \mathrm{E}_{\mathrm{it}}+\mathrm{X}_{\mathrm{ict}} \lambda+\mathrm{Z}_{\mathrm{ct}} \eta+\rho_{\mathrm{c}}+\mu_{\mathrm{t}}+\theta_{\mathrm{i}}+\varepsilon_{\mathrm{ict}}
$$

where $\delta$ captures the differential effect of centralization reforms for eligible voters, $E_{i t}$, compared with non-voters, and $E_{i t}$ is included in $X_{i c t}$. The remaining variables are defined as before, with the only difference being that $\beta$ now captures the effect of centralization reforms for non-voters.

Panel A of table 5 shows evidence of stronger effects for eligible voters compared with non-voters. Whereas the total effect of centralization is negative and statistically significant for eligible voters $(\beta+\delta=-0.073)$, the effect is two times lower and statistically insignificant for non-voters $(\beta=-0.036)$. Although these results must be interpreted with caution, they support the view that for eligible voters, centralization was associated with lower subjective well-being from their ability to influence political decisions. In contrast, the negative but nonstatistically significant effect for non-voters is in line with the assumption that non-voters could not possibly experience procedural disutility as they were not involved in the political decision process in the first place. They also support evidence that non-voters suffered from centralization to a lesser extent.

One concern with this interpretation, however, is that differences in life satisfaction between eligible voters and non-voters may reflect other factors that systematically changed with centralization reforms and did not affect eligible voters and non-voters in the same manner. Comparing eligible voters and non-voters, the latter are on average younger (31 vs. 
49 years old) and more likely to be single (59\% vs. 25\%), foreigners (55\% vs. $1 \%$ ), and less educated (30\% vs. 13\%). ${ }^{18}$ Appendix table A14 replicates the analysis, restricting the sample to individuals aged 18 years or older. Similar results are obtained. To address this concern, table 5, panel B also uses Swiss citizens and foreigners as alternative treated and non-treated groups. Arguably, the assumption that Swiss citizens would react to centralization in the same manner as foreigners (except for their voting status) may be more valid. Foreigners living and working in Switzerland benefit from local public goods and are liable to pay Swiss taxes. Ideally, we would like to focus on foreigners who have lived in Switzerland for a certain number of years and/or will potentially stay for longer (i.e., those with a permanent resident permit). Fortunately, the SHP provides us with such information, and appendix table A14, panel $\mathrm{B}$ shows that the results are remarkably similar when restricting the sample to foreigners with a permanent resident permit. Finally, to ensure that the results are not driven by other omitted variables, column (2) of table 4 controls for additional time-varying characteristics analyzed in section $\mathrm{V}$, such as municipal and cantonal public expenditure, income tax rates, and cantonal fiscal and financial health.

A related concern is that some persons may wish to become an eligible voter/a Swiss citizen with full participation rights as a result of their expected procedural benefit from centralization. However, whether a person may vote is determined by law. As a result, it seems reasonable to assume that selection between eligible voters and non-voters is unlikely to be affected by the centralization reforms. Nevertheless, to account for this, columns (3) and (4) provide robustness checks, including individual-electoral/citizenship fixed effects, and individual-canton fixed effects, to ensure that neither endogenous selection to electoral

\footnotetext{
${ }^{18}$ See appendix table A13.
} 
status/citizenship nor selective migration are driving the results. Again, similar results are obtained. ${ }^{19}$

\section{[Table 5 about here]}

As a final exercise, the results in column (5) of table 5 indicate that eligible voters and Swiss citizens significantly lost political influence after implementation of the reforms, while the effect was not significant for non-voters and foreigners. Although this is unsurprising, given that respondents who neither have the right to vote nor have Swiss nationality cannot possibly suffer from losing political influence, this again supports the claim that centralization decreased individuals' feeling of being able to influence local politics only for those with full participation rights. As a placebo test, column (6) of table 5 demonstrates that centralization did not generate differential effects according to satisfaction with public expenses for these four groups. This is consistent with the hypothesis that eligible voters (or Swiss citizens) reacted in the same manner as non-voters (or foreigners) to centralization reforms-except for their belief in political influence.

\section{Specific Economic and Political Conditions}

The previous sections imply that the welfare impacts of centralization crucially depend on the utility individuals derive from having political influence. In this last section, I build on heterogeneity in the effects across municipalities and cantons to investigate whether these

\footnotetext{
${ }^{19}$ Appendix table A15 provides evidence that centralization had no significant impact on the probability of becoming eligible voters or Swiss citizens. It also provides evidence that eligible voters and Swiss citizens were not more likely to move to other cantons that could be more in accordance with their political preferences (compared with non-voters and foreigners).
} 
welfare effects are sustained or even strengthened under certain economic and political conditions.

Providing more opportunities to participate-even if the stakes of the outcomes are lowered — could be one way to mitigate the negative effects of centralization. Column (1) of table 6 shows that the welfare impacts of centralization were less negative for individuals living in cantons with a higher degree of direct democracy. ${ }^{20}$ A 1 SD increase in direct democracy decreases the effect of centralization by slightly more than $50 \%$.

The effect of centralization was, similarly, less negative in cantons where the centralization reform had been approved with a high margin. I consider two groups: (1) cantons where the centralization reform had been adopted by "consensus" and (2) cantons where the reforms had been approved with a low margin. Swiss residents - in most cantons - were asked to vote for these reforms. The reforms approved with a high margin generated a small negative impact on individuals' life satisfaction — whereas the reforms adopted with a low margin were less likely to be expected and approved, even if they were highly debated, leading to a much larger drop in individuals' well-being after their approval.

Another approach is to take into account potential "political mismatch" effects. Individuals could be less satisfied after introduction of the reforms because the municipal authority or the cantonal authority to which they belong are controlled by parties further away from their preferred political standing. To address this possibility, I add an interaction term between centralization and a dummy equal to 1 if the municipality and the canton of residence have the same political majority. I also add an interaction term between centralization and a dummy

\footnotetext{
${ }^{20}$ I use the index of direct democracy from Stutzer (1999), which is an unweighted average of four indicators that evaluate the power of the different direct democratic institutions across cantons. The index takes values from 1 to 6 , where 6 indicates the highest degree of direct democracy.
} 
equal to 1 if the municipality and the canton of residence have the same political majority. In all cases, however, I do not find significant differential effects.

\section{[Table 6 about here]}

Finally, municipalities having financial difficulties or smaller municipalities might have experienced a lower drop in well-being as they benefited from higher economic gains from centralization. According to columns (6) and (7) of table 6, however, this does not seem to be the case. ${ }^{21}$

\section{Conclusion}

In this paper, I present evidence on the impacts of centralization reforms on individual selfreported well-being from a quasi-natural experiment implemented in Switzerland. Using time and cross-cantonal variation in the implementation of centralization reforms, I find that centralization significantly decreased individuals' life satisfaction. These results are identified for the large and policy-relevant group of citizens who derive benefits from being involved in the political decision-making process. In addition, centralization reforms are found to

${ }^{21}$ I also find no evidence of differential effects of centralization by income groups, health status, presence of children in the household, unemployment, and political preferences (see appendix table A16). By contrast, the effect of centralization reforms is significantly stronger for students, women, and respondents for whom French is their first spoken language. These results are consistent with previous findings if we assume that (i) students are the ones affected by the centralization reforms in school and who perhaps have more expected gains from being involved in the political decision process, (ii) women are on average underrepresented in local institutions and experience lower political influence, and (ii) Frenchspeaking respondents live in cantons with a lower degree of direct democracy. 
decrease individuals' beliefs about political influence and less basic forms of political participation and civic engagement.

Addressing the concerns that centralization could also induce lower efficiency in publicgoods provision, I find no evidence that granting administrative, political, and fiscal capacities to more central levels of government decreased individuals' satisfaction with public expenses. If anything, centralization reforms helped municipalities to deal with economic pressures and allowed them to finance tax cuts, resulting in an increase in household annual income over the period.

Although other mechanisms are likely to be at work, the procedural effects associated with centralization seem to play a key role in shaping individuals' well-being impacts derived from centralization. As these imply some costs, this suggests that minimum economic gains would be necessary before centralization can increase residents' overall well-being. Of course, the focus on individuals' political influence and participation can only partially illuminate the optimal level of (de)centralization. Although I find little evidence that centralization induced economic costs, the reforms decreased the level of public expenditure, mainly in health, school, and social affairs, and are likely to have affected the quality and quantity of local public goods and services. Further research should therefore consider the impact of centralization on health, school, or social outcomes.

Nevertheless, given the ongoing debate about the welfare consequences associated with centralization, establishing that centralization has negative effects on individuals' life satisfaction is a crucial first step in setting a new conceptual framework to investigate how people experience centralization reforms beyond economic efficiency. This reveals the importance of taking into account a key assumption, namely that individuals have a priori innate needs of self-determination (Deci \& Ryan, 2000) and thus derive utility from the procedures or institutions applied. 
More generally, my results call for the need to take issues of procedural utility more into account in the economic discipline. Individuals may value procedural differences in their role not only as voters but also as taxpayers (Frey \& Feld, 2002). New insights into tax compliance, tax evasions, and electoral choices may therefore be gained by including procedural utility in models. Although my empirical analysis considered the effects of shocks on people's political influence due to centralization, the logic may be applied to all those factors that potentially affect people's procedural utility (e.g., political and economic institutions).

\section{References}

Barankay, Iwan, and Ben Lockwood, "Decentralization and the productive efficiency of government: Evidence from Swiss cantons", Journal of Public Economics 91:5-6 (2007), $1197-1218$.

Bardhan, Pranab, and Dilip Mookherjee, "Decentralization, corruption and government accountability", in International Handbook on the Economics of Corruption, S. RoseAckerman, ed. Cheltenham: Edward Elgar, (2006).

Bardhan, Pranab, and Dilip Mookherjee, Decentralization and local governance in developing countries: A comparative perspective, Cambridge, MA: MIT Press (2008).

Bartels, Larry M., Unequal democracy: The political economy of the new gilded age, $2^{\text {nd }}$ edition. Princeton, NJ: Princeton University Press (2016).

Benz, Matthias, and Bruno S. Frey, "Being independent is a great thing. Subjective evaluations of self-employment and hierarchy" Institute for Empirical Research Working Paper. No. 135. University of Zurich (2003).

Benz, Matthias, and Aloïs Stutzer, "Do workers enjoy procedural utility?” Applied Economics Quarterly 49 (2003), 1-32. 
Besley, Timothy, and Stephen Coate "Centralized versus decentralized provision of local public goods: A political economy approach”, Journal of Public Economics 87 (2003), 2611-2637.

Bjornskov, Christian, Alex Dreher, and Justina A.V. Fischer "The bigger, the better? Evidence of the effect of government size on life satisfaction around the world", Public Choice 130:3-4 (2007), 267-292.

Bjornskov, Christian, Alex Dreher, and Justina A.V. Fischer "On decentralization and life satisfaction", Economics Letters 99:1 (2008), 147-151.

Clark, Andrew E., Sarah Flèche, Richard Layard, Nattavudh Powdthavee, and George Ward, The origins of happiness: The Science of wellbeing over the life course, Princeton, NJ: Princeton University Press (2018).

Davoodi, Hamid, and Heng-fu Zou, "Fiscal decentralization and economic growth: A crosscountry study", Journal of Urban Economics 43 (1998), 244-257.

Deci, Edward L., and Richard M. Ryan, "The“what"and"why”of goal pursuits: Human needs and the self-determination of behavior", Psychological Inquiry 11:4 (2000), 227-268.

Diaz-Serrano, Luis, and Andrés Rodriguez-Pose, "Decentralization, subjective well-being and the perception of institutions", Kyklos 65:2 (2012), 179-193.

Dorn, David, Justina A.V. Fischer, Gebhard Kirchgässner, and Alfonso Sousa-Poza, "Is it culture of democracy? The impact of democracy and culture on happiness", Social Indicators Research 82:3 (2007), 505-526.

Downs, Anthony, An Economic Theory of Democracy, New York: Harper (1957).

Enikolopov, Ruben, and Ekaterina Zhuravskaya, "Decentralization and political institutions", Journal of Public Economics 91:11-12 (2007), 2261-2290.

Faguet, Jean-Paul, "Does decentralization increase government responsiveness to local needs? Evidence from Bolivia”, Journal of Public Economics 88:3-4 (2004), 867-893. 
Frey, Bruno S., Matthias Benz, and Aloïs Stutzer, "Introducing procedural utility: Not only what, but also how matters", Journal of Institutional and Theoretical Economics 160 (2004), 377-401.

Frey, Bruno S., and Lars P. Feld, "Deterrence and moral in taxation: An empirical analysis". CESifo Working Paper No. 760 (2002).

Frey, Bruno S., and Werner W. Pommerehne, "On the fairness of pricing - An empirical survey among the general population", Journal of Economic Behavior and Organization 20:3 (1993), 295-307.

Frey, Bruno S., and Aloïs Stutzer, "Happiness, economy and institutions", The Economic Journal 110 (2000), 918-938.

Frey, Bruno S., and Aloïs Stutzer, "What can economists learn from happiness research?" Journal of Economic Literature 40 (2002), 402-435.

Frey, Bruno S., and Aloïs Stutzer, "Beyond outcomes: Measuring procedural utility, Oxford Economic Papers 57:1 (2005), 90-111.

Frey, Bruno S., Aloïs Stutzer, Matthias Benz, Stephan Meier, Simon Luechinger, and Christine Benesch, Happiness: A revolution in economics, Cambridge, MA: MIT Press (2008).

Gao, Song, Xiangyi Meng, and Li Zhang, "Fiscal decentralization and life satisfaction: Evidence from urban China”, Social Indicators Research 119 (2014), 1117-1194.

Gilens, Martin, Affluence and influence: Economic inequality and political power in America, Princeton, NJ: Princeton University Press (2014).

IEB, Report on Fiscal Federalism, Economic crisis and recentralization. IEB. Institut d'Economia de Barcelona (2013).

Iimi, Atsushi, "Decentralization and economic growth revisited: An empirical note", Journal of Urban Economics 57:3 (2005), 449-461. 
Jacot-Descombes, Caroline, «A la croisée des modèles du fédéralisme fiscal et coopératif : les résultats des réformes de répartition des tâches cantons-communes en Suisse », IDHEAP (2013).

Kahneman, Daniel, Peter P. Wakker, and Rakesh Sarin, "Back to Bentham? Explorations of experienced utility", Quarterly Journal of Economics 112:2 (1997), 375-405.

Layard, Richard, Happiness: Lessons from a New Science, London: Penguin (2005).

Lockwood, Ben, "Distributive politics and the costs of centralization", Review of Economic Studies 69 (2002), 313-337.

Ludwig, Jean, Greg J. Duncan, Lisa A. Gennetian, Lawrence F. Katz, Ronald C. Kessler, Jeffrey R. Kling, and Lisa Sanbonmatsu, "Neighborhood effects on the long-term wellbeing of low-income adults", Science 337:6101 (2012), 1505-1510.

Maleski Edmund, Cuong Viet Nguyen, and Anh Tran, "The impact of recentralization on public services: A difference-in-difference analysis of the abolition of elected councils in Vietnam”, American Political Science Review 108 (2014),144-168.

Marmot, Michael, The Status Syndrome. How Social Standing Affects Our Health and Longevity, New York: Time Books (2004).

Michelsen, Claus, Peter Boenish, and Benny Geys, "(De)centralization and voter turnout: Theory and evidence from German municipalities”, Public Choice 159 (2014), 469-483.

Oates, Wallace E., Fiscal Federalism, New York: Harcourt Brace Jovanovich (1972).

OECD Report, Government at a glance, OECD publishing (2013).

Revelli, Federico, “Tax limits and local elections”, Public Choice 166 (2016), 53-68.

Rodriguez-Pose, Andrés and Roberto Ezcurra, "Is fiscal decentralization harmful for economic growth? Evidence from the OECD countries", Journal of Economic Geography 11:4 (2010), 619-643. 
Ruhli, Lukas, «Autonomie communale entre illusion et réalité », Monitoring des cantons 4 : Structures communales et politique structurelle communale des cantons (2012).

Sen, Amartya "Rationality and social choice", American Economic Review 85 (1995), 1-24.

Sepulveda, Christian F., and Jorge Martinez-Vazquez, "The consequences of fiscal decentralization on poverty and income inequality", Environment and Planning C: Government and Policy 29:2 (2011), 321-343.

Schneider, Mark, Paul Teske, Mélissa Marshall, and Christine Roch, "Shopping for schools: In the land of the blind, the one-eyed parent may be enough", American Journal of Political Science 42:3 (1998), 769-793.

Shaker, Lee, "Local political knowledge and assessments of citizen competence", Public Opinion Quarterly 76:3 (2012), 525-537.

Simon, Herbert A., Administrative Behavior, New York: The Free Press (1976).

Simon, Herbert A., Nobel lectures, economics 1969-1980, Singapore: World Scientific Publishing Co (1978).

Solt, Frederick, "Economic inequality and democratic political engagement", American Journal of Political Science, 52:1 (2008), 48-60.

Stutzer, Aloïs, "Demokratieindizes fur die kantone der Schweiz". Working Paper No. 23, Institute for Empirical Research in Economics, University of Zurich (1999).

Stutzer, Aloïs, and Bruno S. Frey, "Political participation and procedural utility: An empirical study", European Journal of Political Research 45 (2006), 3919-418.

Sujarwoto, Sujarwoto, and Gindo Tampubolon, "Decentralization and citizen happiness: A multi-level analysis of self-rated happiness in Indonesia”, Journal of Happiness Studies 16 (2015), 455-475. 
Teske, Paul, Mark, Schneider, Michael Mintrom, and Samuel Best, "Establishing the microfoundations of a macro theory: Information, movers, and the competitive local market for public goods”, American Political Science Review 87 (1993), 702-713.

Tiebout, Charles M., “A pure theory of local expenditures”, Journal of Political Economy 64 (1956), 416-424.

Treisman, Daniel, The architecture of government: Rethinking political decentralization, Cambridge: Cambridge University Press (2007).

Tyler, Tom R.: "Process utility and help seeking: What do people want from experts?", Journal of Economic Psychology 27:3 (2006), 360-376.

Voigt Stephan, and Lorenz Blume, “The economic effects of federalism and decentralization - a cross country assessment”, Public Choice, 151:1-2 (2012), 229-254. 
Figure 1: Impact of the reforms on the degree of local decentralization

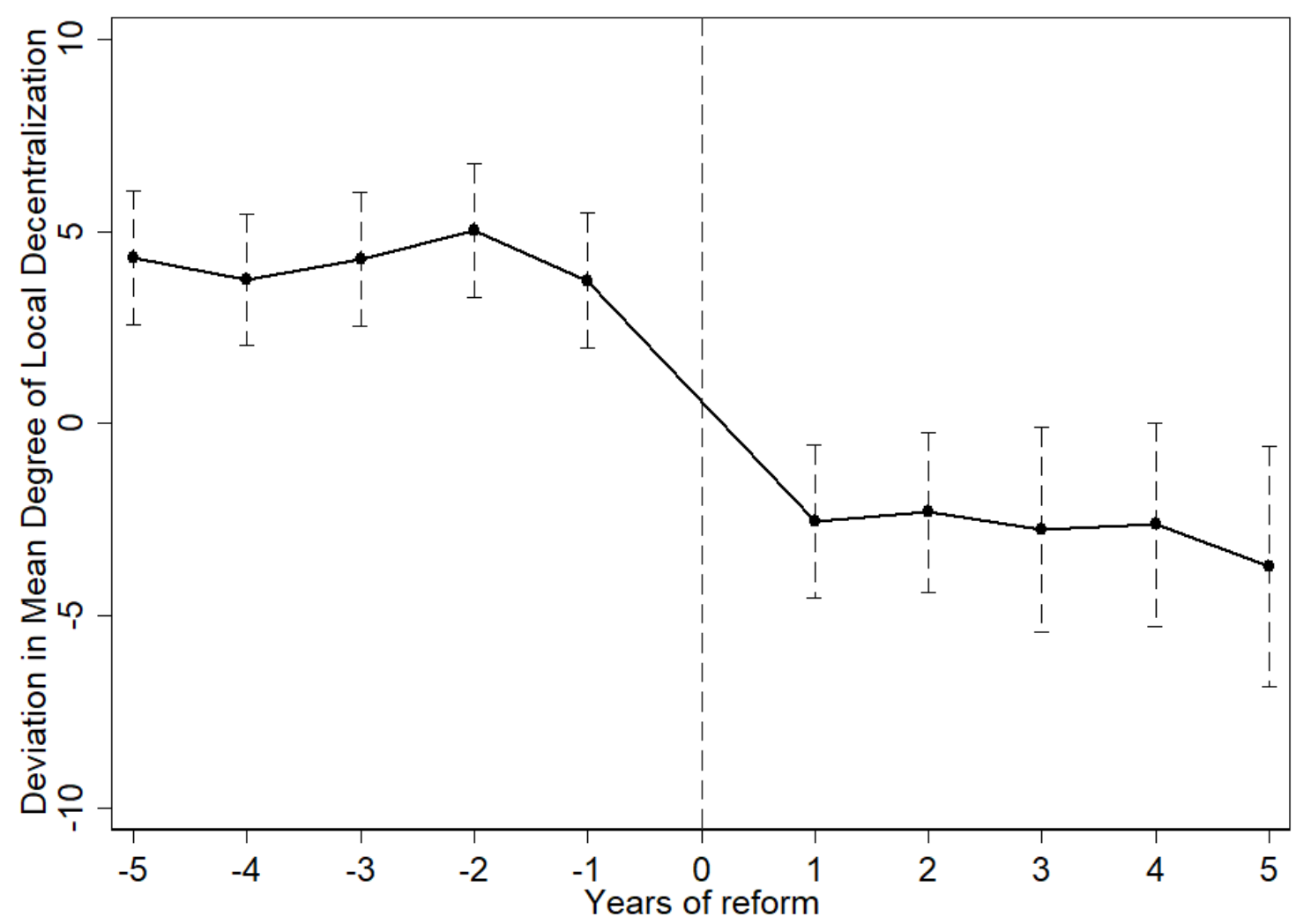

Source: BADAC dataset.

Notes: The degree of local decentralization is defined as the share of municipal expenditure in the total amount of cantonal expenditure (available from 1997 to 2007). Based on 19 cantons and a model where the degree of local decentralization is predicted with canton effects as well as year dummies, which corresponds to years from the implementation of the reforms. The effects of these dummies are plotted on the figure. Vertical bands represent 1.65 times the standard error of each point estimate. 
Figure 2: Timing of implementation of the centralization reforms

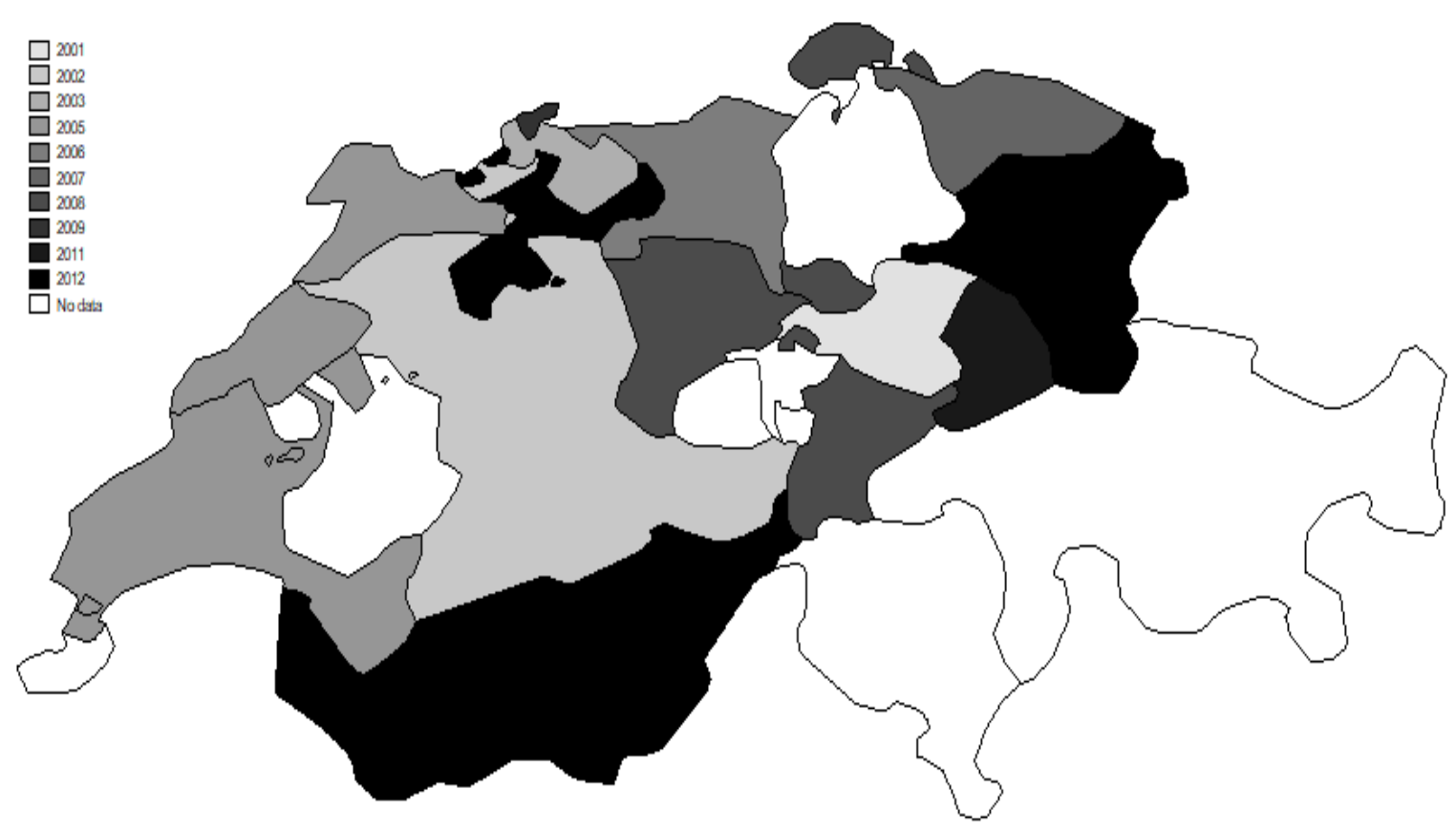


Figure 3: Pre-trends in life satisfaction, by treatment groups

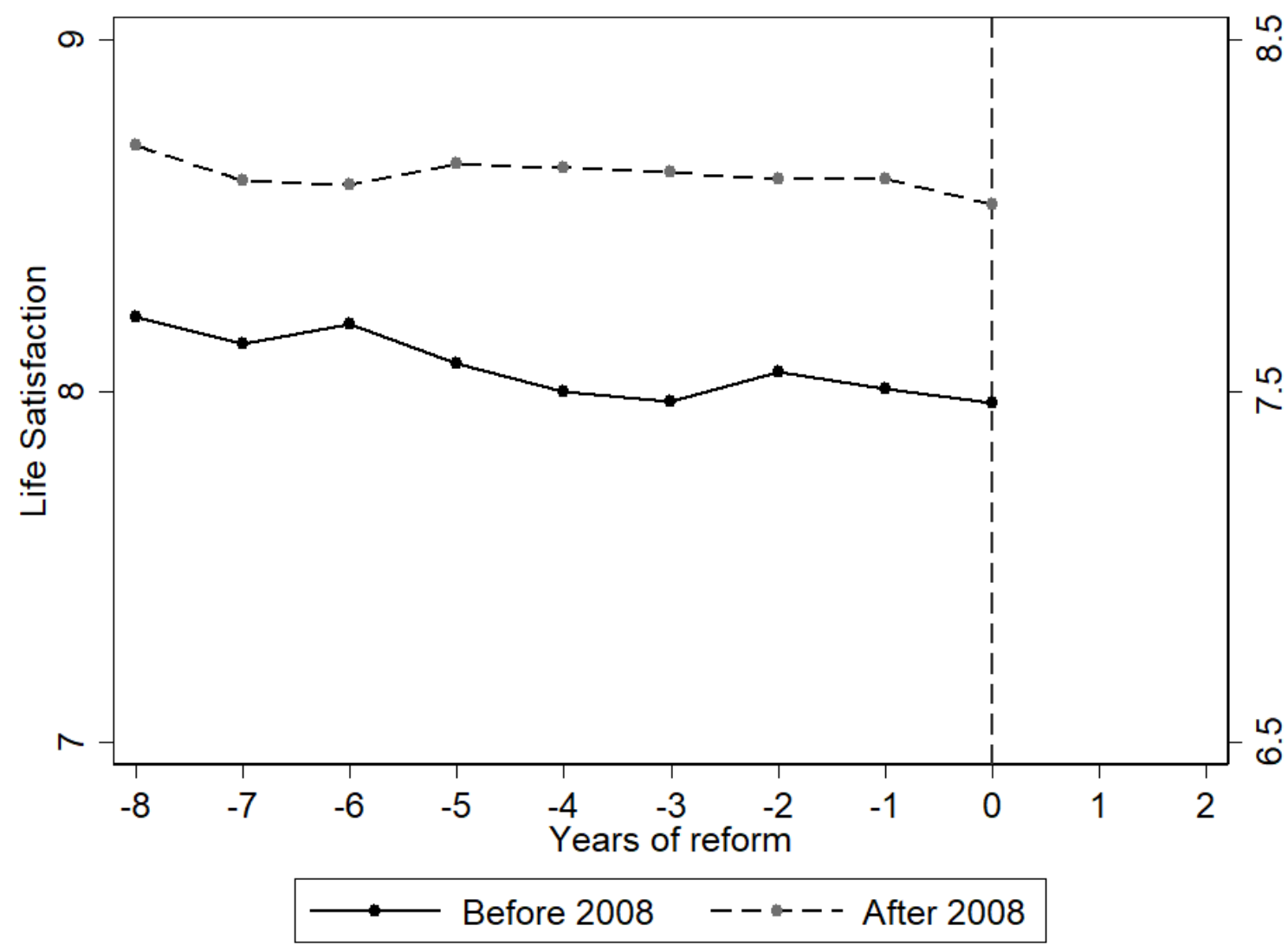

Source: SHP data.

Notes: Each dot represents the average life satisfaction by year up to the implementation of the reforms and by treatment groups (whether the reform was implemented before or after 2008). The graph shows roughly similar pre-trends across treatment groups. 
Table 1: Effects of centralization reforms on life satisfaction (2000-2014)

\section{Life satisfaction}

(1)

(2)

(3)

(4)

(5)

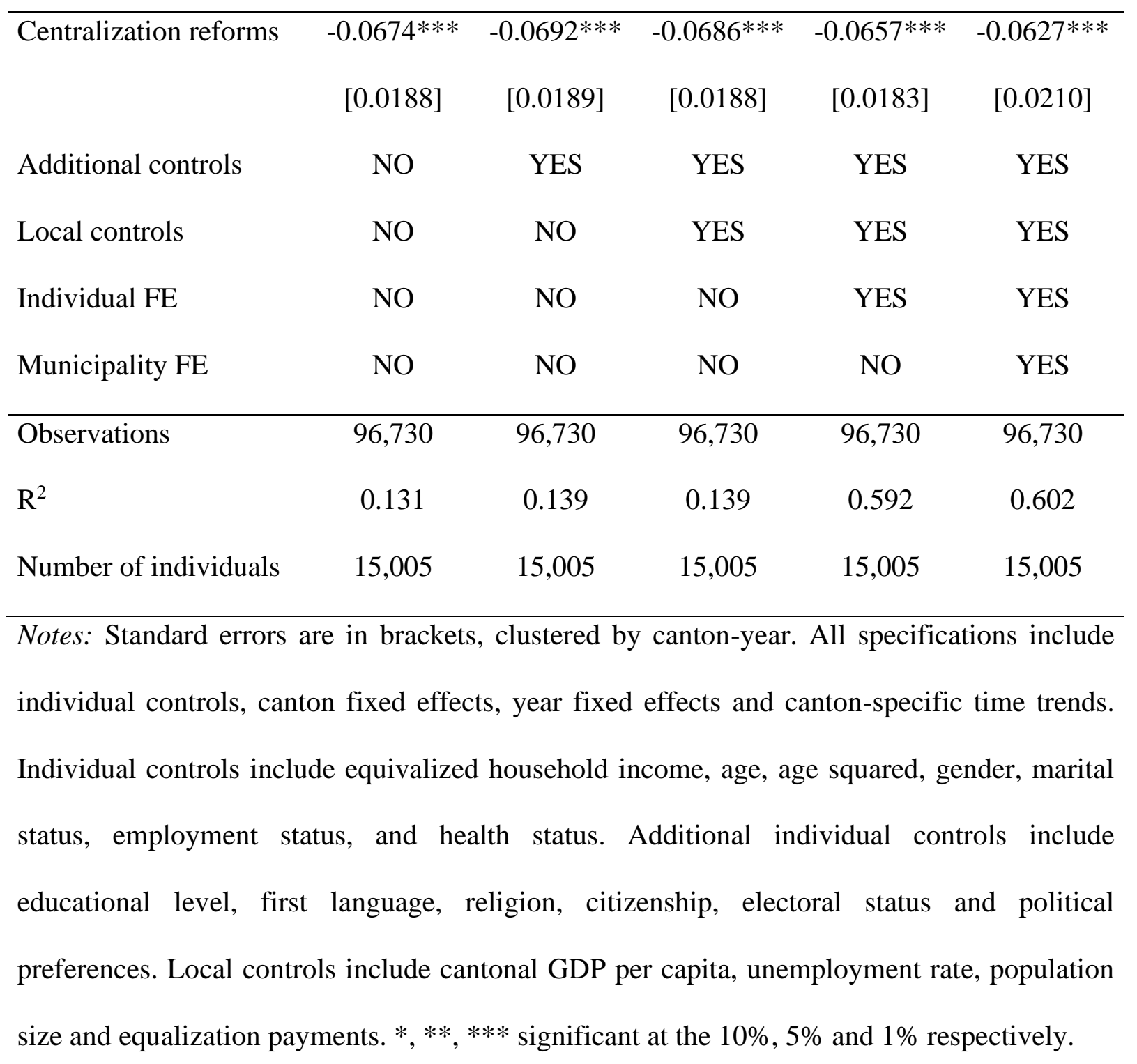


Table 2: Falsification tests and robustness checks

\section{Life satisfaction}

$\begin{array}{llll}\text { Coef. } & \text { S.E. } & \text { Obs } & \mathrm{R}^{2}\end{array}$

\section{Panel A: Falsification tests}
(1) 4 years prior
0.0300
[0.0189]
96,730
0.592
(2) 3 years prior
0.0340
$[0.0254] \quad 96,730$
0.592
(3) 2 years prior
$-0.0010$
[0.0212] 96,730
0.592

\section{Panel B: Robustness checks}

(4) Cantons of residence in 2000

$$
-0.0628 * * *
$$

$[0.0173]$

58,657

0.588

(5) With individual-canton FE

$$
-0.0608 * * *
$$

[0.0200]

96,730

0.598

(6) Probit adjusted OLS

$$
-0.0543 * * *
$$

[0.0190]

96,730

0.510

(7) Reformeduc $\mathrm{ct}$

$$
-0.0643 * * *
$$

[0.0189]

96,730

0.592

(8) Reformhealth ct

$-0.0772 * * *$

$[0.0227]$

96,730

0.592

(9) Reformsocial ${ }_{\mathrm{ct}}$

$-0.0757 * * *$

[0.0219]

96,730

0.592

(10) Interaction with intensity (1)

$-0.0025^{* * *}$

[0.0009]

79,078

0.590

(11) Interaction with intensity (2)

$-0.0104 * * *$

[0.0039]

68,523

0.593

Notes: Standard errors are in brackets, clustered by canton-year. All specifications include individual controls, local controls, canton fixed effects, year fixed effects, canton-specific time trends and individual fixed effects. Individual and local controls are the same as those include in table $1 . * * *, * * *$ significant at the $10 \%, 5 \%$ and $1 \%$ respectively. 
Table 3: Effect of centralization reforms on public goods provision and local public finance

\begin{tabular}{|c|c|c|c|c|c|c|c|c|c|c|}
\hline & \multicolumn{3}{|c|}{ Public goods provision } & \multicolumn{6}{|c|}{ Municipal and cantonal fiscal capacity } & \multirow[b]{2}{*}{$\begin{array}{c}\text { HH } \\
\text { annual } \\
\text { income } \\
(\log ) \\
(10)\end{array}$} \\
\hline & $\begin{array}{c}\text { Municipal } \\
\text { expenditure } \\
\text { per capita } \\
\text { (in CHF) } \\
\text { (1) }\end{array}$ & $\begin{array}{c}\text { Cantonal } \\
\text { expenditure } \\
\text { per capita } \\
(\text { in } C H F) \\
\text { (2) }\end{array}$ & $\begin{array}{c}\text { Satisfied } \\
\text { with public } \\
\text { spending } \\
(1,0) \\
(3)\end{array}$ & $\begin{array}{c}\text { Municipal } \\
\text { income tax } \\
\text { rates } \\
(0-1) \\
(4)\end{array}$ & $\begin{array}{c}\text { Cantonal } \\
\text { income tax } \\
\text { rates } \\
(0-1) \\
(5)\end{array}$ & $\begin{array}{c}\text { Municipal } \\
\text { revenue } \\
(1-5) \\
(6)\end{array}$ & $\begin{array}{c}\text { Municipal } \\
\text { debt } \\
(1-5) \\
\text { (7) }\end{array}$ & $\begin{array}{c}\text { Cantonal } \\
\text { financial } \\
\text { health } \\
(1-6) \\
(8)\end{array}$ & $\begin{array}{c}\text { Cantonal } \\
\text { financial } \\
\text { management } \\
(1-6) \\
(9)\end{array}$ & \\
\hline Centralization reforms & $-36.53 * * *$ & $-320.7 * *$ & 0.0052 & $-0.0041 * * *$ & $-0.0029 * * *$ & $-0.240 * * *$ & -0.0841 & 0.113 & 0.0874 & $0.0118^{*}$ \\
\hline & {$[8.762]$} & {$[137.0]$} & {$[0.006]$} & {$[0.0014]$} & {$[0.0011]$} & {$[0.0894]$} & {$[0.0707]$} & {$[0.237]$} & {$[0.157]$} & {$[0.007]$} \\
\hline Canton-specific time trends & YES & NO & YES & YES & NO & YES & YES & NO & NO & YES \\
\hline Individual controls & NO & NO & YES & NO & NO & NO & NO & NO & NO & YES \\
\hline Individual FE & NO & NO & YES & NO & NO & NO & NO & NO & NO & YES \\
\hline Observations & 39,270 & 390 & 92,851 & 39,270 & 390 & 6,400 & 6,426 & 390 & 390 & 96,788 \\
\hline $\mathrm{R}^{2}$ & 0.104 & 0.966 & 0.494 & 0.753 & 0.931 & 0.131 & 0.095 & 0.464 & 0.512 & 0.707 \\
\hline Number of individual units & 2,618 & 26 & 14,230 & 2,618 & 26 & 2,491 & 2,492 & 26 & 26 & 15,011 \\
\hline Years & $00-14$ & $00-14$ & $00-14$ & $00-14$ & $00-14$ & $\begin{array}{c}98,05,09 \\
16\end{array}$ & $\begin{array}{l}98,05, \\
09,16\end{array}$ & $00-14$ & $00-14$ & $00-14$ \\
\hline
\end{tabular}

Notes: Standard errors are in brackets, clustered by canton-year. All specifications include local controls, canton fixed-effects and year fixedeffects. Individual and local controls are the same as those include in table $1 . *, * * * * *$ significant at the $10 \%, 5 \%$ and $1 \%$ respectively. 
Table 4: Effect of centralization reforms on political influence and participation

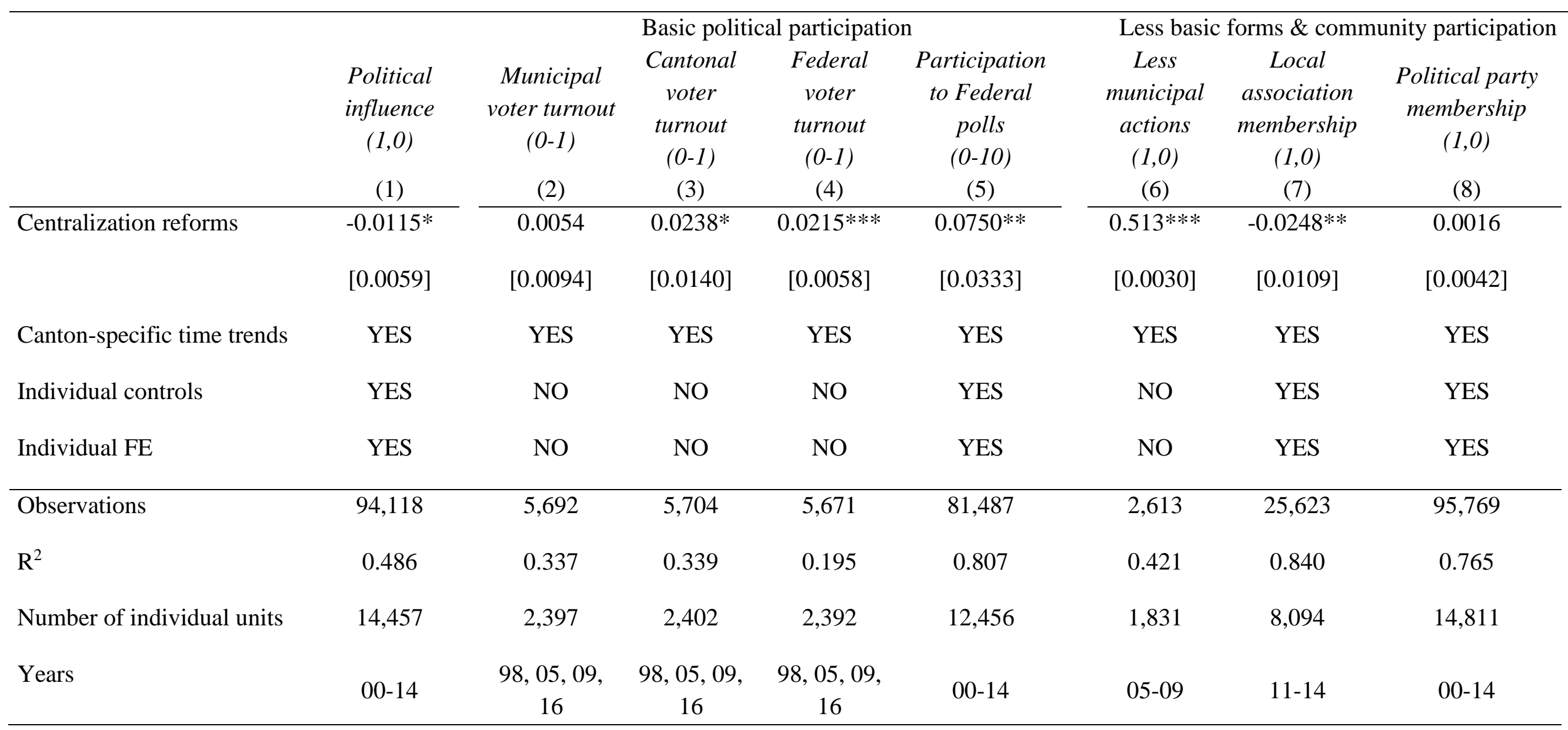

Notes: Standard errors are in brackets, clustered by canton-year. All specifications include local controls, canton fixed-effects and year fixed-

effects. Individual and local controls are the same as those include in table $1 . *, * *, * * *$ significant at the $10 \%, 5 \%$ and $1 \%$ respectively. 
Table 5: Estimated triple differences by electoral status and citizenship

\begin{tabular}{|c|c|c|c|c|c|c|}
\hline Total effects: & (1) & Life sati & faction & (4) & $\begin{array}{c}\text { Feeling } \\
\text { about } \\
\text { political } \\
\text { influence } \\
\text { (5) }\end{array}$ & $\begin{array}{c}\text { Satisfied } \\
\text { with public } \\
\text { spending } \\
\text { (6) }\end{array}$ \\
\hline \multicolumn{7}{|l|}{ Panel A: Electoral status } \\
\hline Non-eligible & -0.0357 & -0.0221 & -0.0468 & 0.0030 & 0.0047 & 0.0119 \\
\hline & {$[0.0400]$} & {$[0.0398]$} & {$[0.0596]$} & {$[0.0438]$} & {$[0.0133]$} & {$[0.0110]$} \\
\hline Eligible to vote & $\begin{array}{c}-0.0725 * * * \\
{[0.0173]}\end{array}$ & $\begin{array}{c}-0.0602 * * * \\
{[0.0175]}\end{array}$ & $\begin{array}{c}-0.0596 * * * \\
{[0.0201]}\end{array}$ & $\begin{array}{c}-0.0589 * * * \\
{[0.0191]}\end{array}$ & $\begin{array}{c}-0.0140 * * \\
{[0.0059]}\end{array}$ & $\begin{array}{c}0.0051 \\
{[0.0065]}\end{array}$ \\
\hline Additional local controls & NO & YES & YES & YES & YES & YES \\
\hline Individual -electoral FE & NO & NO & YES & NO & NO & NO \\
\hline Individual -canton FE & NO & NO & NO & YES & $\mathrm{NO}$ & NO \\
\hline Observations & 96,730 & 96,730 & 96,730 & 96,730 & 94,118 & 92,851 \\
\hline $\mathrm{R}^{2}$ & 0.592 & 0.592 & 0.592 & 0.592 & 0.500 & 0.494 \\
\hline \multicolumn{7}{|l|}{ Panel B: Citizenship } \\
\hline Foreigners & $\begin{array}{l}-0.0278 \\
{[0.0556]}\end{array}$ & $\begin{array}{c}-0.0137 \\
{[0.0550]}\end{array}$ & $\begin{array}{l}-0.0251 \\
{[0.0646]}\end{array}$ & $\begin{array}{c}0.0268 \\
{[0.0617]}\end{array}$ & $\begin{array}{l}-0.0050 \\
{[0.0160]}\end{array}$ & $\begin{array}{c}0.0096 \\
{[0.0136]}\end{array}$ \\
\hline Swiss citizens & $\begin{array}{c}-0.0719 * * * \\
{[0.0169]}\end{array}$ & $\begin{array}{c}-0.0596 * * * \\
{[0.0172]}\end{array}$ & $\begin{array}{c}-0.0587 * * * \\
{[0.0188]}\end{array}$ & $\begin{array}{c}-0.0596 * * * \\
{[0.0187]}\end{array}$ & $\begin{array}{l}-0.0114 * \\
{[0.0059]}\end{array}$ & $\begin{array}{c}0.0058 \\
{[0.0065]}\end{array}$ \\
\hline Additional local controls & NO & YES & YES & YES & YES & YES \\
\hline Individual -citizenship FE & NO & NO & YES & NO & NO & NO \\
\hline Individual -canton FE & NO & NO & NO & YES & NO & NO \\
\hline Observations & 96,730 & 96,730 & 96,730 & 96,730 & 94,118 & 92,851 \\
\hline $\mathrm{R}^{2}$ & 0.592 & 0.592 & 0.592 & 0.592 & 0.500 & 0.494 \\
\hline
\end{tabular}

Notes: Standard errors are in brackets, clustered by canton-year. Additional local controls include cantonal and municipal expenditure, cantonal and municipal tax rates, municipal revenue and municipal debt, cantonal fiscal health and cantonal financial management (see table 3). Each block shows the total effects of centralization by electoral and citizenship status. $*, * *, * * *$ significant at the $10 \%, 5 \%$ and $1 \%$ respectively. 
Table 6: Effects of centralization reforms under certain economic and political conditions

\begin{tabular}{lcccccc}
\hline & & \multicolumn{3}{c}{ Life satisfaction } \\
& $\begin{array}{c}\text { Centralization } \\
\text { reforms }\end{array}$ & S.E. & $\begin{array}{c}\text { Interacted } \\
\text { term }\end{array}$ & S.E. & Obs. & $\mathrm{R}^{2}$ \\
\hline Interaction with: & & & & & & \\
(1) Direct democracy & $-0.266 * * *$ & {$[0.0682]$} & $0.0513 * * *$ & {$[0.0168]$} & 96,730 & 0.592 \\
(2) Low margin & $-0.0329 *$ & {$[0.0189]$} & $-0.141^{* * *}$ & {$[0.0430]$} & 96,730 & 0.592 \\
(3) Same political majority (I) & $-0.0652 * * *$ & {$[0.0186]$} & -0.0166 & {$[0.0221]$} & 96,730 & 0.592 \\
(4) Same political majority (II) & $-0.0657 * * *$ & {$[0.0183]$} & -0.0140 & {$[0.0580]$} & 96,730 & 0.592 \\
(5) Same political majority (III) & $-0.0654 * * *$ & {$[0.0184]$} & -0.0893 & {$[0.122]$} & 96,730 & 0.592 \\
(6) Small municipalities & $-0.0595 * * *$ & {$[0.0193]$} & -0.0320 & {$[0.0360]$} & 96,730 & 0.592 \\
(7) In financial difficulties & $-0.0620 * * *$ & {$[0.0181]$} & 0.0068 & {$[0.0264]$} & 96,730 & 0.592
\end{tabular}

Notes: Standard errors are in brackets, clustered by canton-year. All specifications include individual controls, local controls, canton fixed effects, year fixed effects, canton-specific time trends and individual fixed effects. Each row shows the effects of one regression where the treatment variable (centralization reforms) is interacted with (1) the degree of direct democracy in the canton of residence; or (2) a dummy whether the reform has been accepted with a low margin; or (3) a dummy whether municipal and canton have the same majority; or (4) a dummy whether canton and respondent have the same majority; or (5) a dummy whether municipal and respondent have the same majority; or (6) a dummy whether municipality of residence is in the bottom $20 \%$ of municipality size; or (7) a dummy whether municipality of residence is in the bottom $20 \%$ of the fiscal health indicator. The first column displays the coefficients associated with the treatment variable and "Interacted term" displays the coefficients associated with the interaction term. $* * * * * *$ significant at the $10 \%, 5 \%$ and $1 \%$ respectively. 